\title{
Microbial quality and shelf life prediction of vacuum-packaged ready to eat beef rounds containing gum arabic
}

\author{
Johnson K. Mhove ${ }^{\mathrm{a}}$, Symon M. Mahungu ${ }^{\mathrm{a}}$, Lilian A. Gogo ${ }^{\mathrm{a}}$, Ben N. Chikamai ${ }^{\mathrm{b}}$, \\ AND MARY OMWAMBA ${ }^{\mathrm{a}}$ \\ ${ }^{\mathrm{a}}$ Department of Dairy and Food Science and Technology, Egerton University, PO Box 536 - 20115, Egerton, \\ Kenya \\ b Kenya Forest Research Institute, PO Box 20412 - 00200, Nairobi, Kenya \\ ${ }^{*}$ Corresponding author \\ smahungu@yahoo.com \\ TEL: +254-720-961031
}

Received: 30 July 2016; Published online: 18 April 2017

\begin{abstract}
Research has shown that gum arabic from Acacia Senegal var. kerensis can be used in beef rounds, at a level of $2.5 \%$ of the formulated product weight, as a binder and texture modifier. However, the effect of gum arabic addition on the microbial quality and shelf life of the resulting meat product has not yet been reported. Thus, the objective of this work was to study the microbial quality of beef rounds containing 2.5\% gum arabic and to study shelf life based on the growth parameters of Total Viable Counts (TVC) and Lactic Acid Bacteria (LAB). Beef round samples were injected at 30\% with curing brines containing gum arabic and cooked through boiling. The growth kinetics of LAB and TVC were studied for vacuum packaged sliced beef round samples stored at $7{ }^{\circ} \mathrm{C}$ and $15{ }^{\circ} \mathrm{C}$ for a period of 21 days. Baranyi and modified Gompertz models were used to fit the LAB and TVC data obtained using DMFit. Results of microbial analysis indicated that coliforms, yeasts and molds as well as pathogenic bacteria; Salmonella, Escherichia coli, and Staphylococcus aureus, were below detection limit. In addition, TVC and LAB were found to be $1.87 \pm 1.09$ and $1.25 \pm 0.75 \log _{10} \mathrm{CFU} \mathrm{g}^{-1}$, respectively. The results of accuracy analysis showed that both the Baranyi and modified Gompertz models were adequate in representing the bacterial growth in beef rounds injected with curing brines containing gum arabic. The predicted shelf life was found to be between $84.3-88.1 \mathrm{~h}$ and $158.0-$ $173.1 \mathrm{~h}$ at $15^{\circ} \mathrm{C}$ and $7{ }^{\circ} \mathrm{C}$, respectively.
\end{abstract}

Keywords: Gum Arabic; Injection Brine; Modeling Growth; Shelf-Life Prediction; Beef Rounds

\section{Introduction}

New product development, involving changes in formulation or processing method, has the potential to influence the intrinsic properties of meat products. The intrinsic properties determine the survival of bacteria in such foods and the possibility of spoilage occurring, with the potential of causing food infections or food intoxications which are a major challenge in the meat industry
(Simonin, Duranton, \& de Lamballerie, 2012). Meat spoilage is from a smaller fraction of specific spoilage organisms (SSO), called ephemeral spoilage organisms (ESO), which require control measures during processing and eventual storage of the meat product (Nychas, Skandamis, Tassou, \& Koutsoumanis, 2008). Their survival in turn depends on the intrinsic properties of the meat. For instance, the normal $\mathrm{pH}$ of meat ranges between $5.5-6.0$, which is opti- 
mum for most bacterial growth. In addition, vacuum packaged Ready To Eat (RTE) meat products have high water activity, low oxygen concentration and an acidic environment that make them highly susceptible to spoilage during storage (Slongo et al., 2009).

Gum arabic, an exudate from Acacia Senegal is an approved food additive that is acceptable as a stabilizer and emulsifier in the food industry (Joint (FAO/WHO, 2005) Expert Committee on Food Additives). In meat, gum arabic from $A c a-$ cia Senegal variety Kerensis has been found to be a suitable binder and extender in beef rounds at a level of $2.5 \%$ of the product formulation (Mwove, Gogo, Chikamai, Omwamba, \& Mahungu, 2016). However, the effect of its incorporation in beef rounds on the microbial quality and the shelf life is yet to be reported. Since its incorporation has the potential to change the intrinsic properties of meat, microbial quality and shelf life evaluation are important.

Cured meats processed as RTE are mostly populated by LAB in very low amounts. LAB are thus regarded as SSO in vacuum packaged cooked RTE meat products, probably due to their dominance in the total bacterial count (Slongo et al., 2009; Kreyenschmidt et al., 2010; Li et al., 2013). When properly cooked, meat products will have minimal contaminating microorganisms. However, LAB are heat resistant and ubiquitously distributed in the environment (Hongpattarakere, Rattanaubon, \& Buntin, 2013). Cooked meats are therefore easily contaminated from the working environment or equipment surfaces during manufacturing processes such as slicing or packaging (Hamasaki, Ayaki, Fuchu, Sugiyama, \& Morita, 2003; Feng, Sun, Martin, \& Zhang, 2013). A number of LAB species have been identified as predominant micro-flora contaminating cured beef products. Hamasaki et al. (2003) identified Leuconostoc mesenteroides subsp. mesenteroides, Lactococcus lactis subsp. Lactis and Leuconostoc citreum from cooked meats stored below $10{ }^{\circ} \mathrm{C}$ while Samelis and Georgiadou (2000) identified Lactobacillus sakei as the dominant species among LAB contaminating stored sausages. These LAB being facultative anaerobes are thus very difficult to control (Perez-Chabela, Lara-Labastida, RodriguezHuezo, \& Totosaus, 2013). They grow, result- ing in spoilage of such vacuum packaged meat products, at refrigeration temperatures as low as $4{ }^{\circ} \mathrm{C}$ (Hamasaki et al., 2003). Bacterial action can further encourage growth of other micro flora. The organic acids accumulated due to LAB biochemical metabolism may eventually stimulate growth of yeasts (Aggelis, Samelis, \& Metaxopoulos, 1998). Since, bacterial action has been identified as the main cause of spoilage in meat based vacuum packaged products, there is a need to determine the microbial quality of such meat products. In the process of new product development when making changes to the product, accelerated shelf life testing (ASLT) will allow for a quick estimation of the approximate shelf life of the product (Fu \& Labuza, 1997). Therefore, understanding the growth parameters of LAB in cured meat products will facilitate their effective control as well as the determination of the viable shelf life of such cured RTE meat products. Such determinations have been achieved through predictive mathematical modeling which is an upcoming alternative to time consuming and expensive traditional microbial enumeration methods for studying bacterial growth (Mataragas, Skandamis, Nychas, \& Drosinos, 2007; Slongo et al., 2009; Li et al., 2013). LAB growth in vacuum packaged cooked meat products has been used in many modeling studies to predict the shelf life of meat products treated by divergent vacuum packaging conditions (Liu, Yang, \& Li, 2006; Slongo et al., 2009) or stored at diverse temperatures (Cayre, Vignolo, \& Garro, 2003; Li et al., 2013). However, there are no reports on the effect of addition of gum arabic from Acacia Senegal var. kerensis in beef rounds on the microbial quality and hence the shelf life of the resulting product. Therefore, the aim of the present work was to determine the microbial quality of beef rounds formulated with $2.5 \%$ gum arabic as a binder, and to study the growth parameters of TVC and LAB in vacuum packaged RTE beef rounds stored at $7{ }^{\circ} \mathrm{C}$ and $15^{\circ} \mathrm{C}$ for 21 days using Baranyi and modified Gompertz models. 


\section{Materials and Methods}

\subsection{Product preparation}

Samples were prepared at Castle Meat Products factory, Egerton, Nakuru, Kenya. Samples weighing $3.5 \mathrm{~kg}$ obtained from the beef round were trimmed of excess fat and injected using a manual injector (Friedr. DICK Hand Brine Injector Pump) at 30\% injection level with brine containing $2 \%$ sodium chloride, $0.02 \%$ sodium nitrate, $0.5 \%$ Sodium tripolyphosphate, $0.0547 \%$ sodium ascorbate and $2.5 \%$ gum arabic. After injection the beef rounds were uniformly massaged by hand for $20 \mathrm{~min}$ at intervals of $20 \mathrm{~min}$ for 3 hours to evenly distribute the brine. The beef rounds were kept in a cold room for 18 hours at $4{ }^{\circ} \mathrm{C}$ after which they were cooked by boiling in water set at $85^{\circ} \mathrm{C}$ for $4-5$ hours until an internal temperature of $75{ }^{\circ} \mathrm{C}$ was reached. Temperature was monitored using a thermometer (TTX 110, Ebro, Ingolstadt, Germany). Samples were then allowed to cool under refrigeration to an internal temperature of $4{ }^{\circ} \mathrm{C}$ before slicing.

\subsection{Packaging}

After preparation, cooking and cooling, beef rounds were immediately aseptically sliced using a slicing machine (Tecmal Torino, Italy) and packed into sterile low-density polyethylene sterile vacuum bags (length $30 \mathrm{~cm}$, width $20 \mathrm{~cm}$ ), which were transparent, strong and resistant to gas exchange. Each package contained approximately 50 grams of beef round. The vacuum bags were specifically designed for use with the vacuum sealing packaging system (Multivac, Germany).

\subsection{Determination of microbial quality}

The microbiological analysis was performed following AOAC Official Methods (AOAC, 2000) to determine the presence of spoilage and pathogenic organisms in beef rounds injected with curing brine containing gum arabic. All samples were analyzed immediately after packaging. Approximately 25 grams of beef round sam- ple was drawn aseptically and blended with 225 $\mathrm{ml}$ of sterile peptone water for 2 minutes. Serial decimal dilutions were then made using sterile peptone diluent. For each dilution, two replicate plates were prepared. Total viable counts were determined by pour plating onto Plate Count Agar (PCA; Oxoid, UK), and incubating at 37 ${ }^{\circ} \mathrm{C}$ for 24 hours. LAB were counted after pour plating onto de Man, Rogosa and Sharpe (MRS; Oxoid, UK) agar plates, and incubating at $35^{\circ} \mathrm{C}$ for 3 days in anaerobic atmosphere. Yeast and mold counts were determined by pour plating onto potato dextrose agar (PDA; Oxoid, UK), and incubating at $25{ }^{\circ} \mathrm{C}$ for 5 days. Coliforms were determined by pour plating onto McConkey agar (Oxoid, UK), and incubating at $35{ }^{\circ} \mathrm{C}$ for 24 hours. Staphylococcus aureus was counted after pour plating onto Baird-parker agar (Oxoid, UK), and incubating for $35-37^{\circ} \mathrm{C}$ for 48 hours, while Salmonella was detected by preenrichment on Rappaport Vassiliadis broth, incubation at $35{ }^{\circ} \mathrm{C}$ for $18-24$ hours, followed by sub culturing onto Xylose-Lysine Deoxycholate Agar (XLD; Oxoid, UK) plates, and incubation of plates at $35{ }^{\circ} \mathrm{C}$ for $18-24$ hours. Identification of bacteria was performed by streaking on agar plates to obtain pure colonies, followed by gram staining, catalase and oxidase tests. Results were expressed as $\mathrm{CFU} \mathrm{g}^{-1}$.

\subsection{Storage and bacterial enumeration for shelf life prediction}

After packaging, samples were divided into two sets, each containing 21 sample packages. One set was stored under refrigeration at $7{ }^{\circ} \mathrm{C}$ and the other set at $15{ }^{\circ} \mathrm{C}$ for up to 21 days. Temperature was measured using a temperature data logger (K202; Voltcraft, Hirschau). Three replicate samples from each refrigerator were collected for analysis on days $0,1,3,7,12,15$ and 21 . Bacterial enumeration for LAB and TVC was performed according to (AOAC, 2000) as above. Results were expressed as $\mathrm{CFU} \mathrm{g}^{-1}$, and data were used for primary predictive modeling using the Baranyi and modified Gompertz models. 


\subsection{Modeling of lactic acid bacteria and total viable counts}

To determine the keeping quality of RTE beef rounds, the growth of lactic acid bacteria was modeled to predict the shelf life of beef rounds of good quality containing gum arabic. The end of shelf life was taken as the point when the number of lactic acid bacteria exceeded $7 \log _{10} \mathrm{CFU} \mathrm{g}{ }^{-1}$ according to Kreyenschmidt et al. (2010). This is because bacterial growth increases during refrigerated storage, possibly causing evident deterioration when the count reaches 7 to $8 \log _{10} \mathrm{CFU}$ $\mathrm{g}^{-1}$ (Santos et al., 2005; Vermeiren, Devlieghere, De Graef, \& Debevere, 2005). The Baranyi and modified Gompertz models were used in primary modelling to fit the TVC and LAB data obtained using CompBase, DMFit version 3.5 (Institute of Food Research, Norwich, UK, http://www. ComBase.cc). The Baranyi model (Baranyi \& Roberts, 1994) is represented by equation 1 .

$\ln (N(t))=N_{o}+\mu_{\max } A(t)-\ln \left(1+\frac{e^{\mu_{\max } A(t)}-1}{e^{N_{\max }-N_{o}}}\right)$

$A(t)=t+\frac{1}{\mu_{\max }} \ln \left(e^{\mu_{\max } t}+e^{-\mu_{\max } \lambda}+e^{-\mu_{\max }(t+\lambda)}\right)$

Where $\ln (N(\mathrm{t}))$ is the $\log$ of cell concentration at time $\mathrm{t}(\mathrm{h})\left(\mathrm{CFU} \mathrm{g}{ }^{-1}\right),\left(N_{o}\right)$ is the log of initial cell concentration $\left(\mathrm{CFU} \mathrm{g}^{-1}\right), \mu_{m} a x$ is the exponential growth rate $\left(\log _{10}\left(\mathrm{CFU} \mathrm{g} \mathrm{g}^{-1} \mathrm{~h}^{-1}\right)\right.$, $\ln \left(N_{m} a x\right)$ is the log of final cell concentration, $\lambda$ is the lag time and $A(t)$ is as shown above (equation 2).

The modified Gompertz model (Gibson \& Roberts, 1989) is represented by equation 3:

$$
\ln (N(t))=N_{o}+N_{\max } e^{-e^{-\mu(t-M)}}
$$

Where $\ln (N(t))$ is the logarithm of microbial counts $\left[\log _{10}\left(\mathrm{CFU} \mathrm{g}^{-1}\right)\right]$ at time $t(\mathrm{~h}), \mathrm{N}_{o}$ is the asymptotic log count as time decreases indefinitely $\left[\log _{10}\left(\mathrm{CFU} \mathrm{g} \mathrm{g}^{-1}\right)\right], N_{\max }$ is the $\log$ count increment as time increases indefinitely $\left[\log _{10}\left(\mathrm{CFU} \mathrm{g}^{-1}\right)\right], \mu_{\max }$ is the relative maximum growth rate at time $M\left[\mathrm{day}^{-1}\right]$, and $M$ is the time required to reach the maximum rate of growth (h).

\subsection{Accuracy analysis and model comparison}

The Root Mean Square Error (RMSE) and regression coefficient $\left(\mathrm{R}^{2}\right)$ were used. The lower the Mean Squares Error (MSE), the better the adequacy of the model to describe the data (Sutherland, Bayliss, \& Roberts, 1994). A $\mathrm{R}^{2}$ value equal or close to 1 indicates a good fit.

\section{Results and Discussion}

\subsection{The microbial quality of RTE beef round}

For some samples, microorganisms were below detectable limits. TVC were found to be 1.87 $\pm 1.09 \mathrm{CFU} \mathrm{g}^{-1}$ while $\mathrm{LAB}$ were $1.25 \pm 0.75$ $\mathrm{CFU} \mathrm{g}{ }^{-1}$. Coliforms, yeasts and molds were below detection limit. In addition, pathogenic bacteria; Salmonella, Escherichia coli, and Staphylococcus aureus were not detectable in $25 \mathrm{~g}$ sample of the beef rounds. Steele and Stiles (1981) found that other bacteria, including Microbacterium thermosphactum, micrococci and group D streptococci are of minor importance in sliced hams. This is because vacuum packaged meat is mostly affected by psychrotrophic facultative anaerobic and anaerobic bacteria (Ray \& Bhunia, 2007). The levels of LAB were found to be low and comparable to the TVC. About $67 \%$ of the TVC population was found to be LAB. Vacuum packaged RTE meat products have been reported to be highly prone to LAB spoilage due to their high water activity, low oxygen concentration and acidic environments (Slongo et al., 2009). Since analysis was performed immediately after slicing and packaging, most bacteria were not detectable. Since the counts of Lactic acid bacteria were comparable to those of TVC, LAB are confirmed to be the specific spoilage organisms in vacuum packaged RTE beef rounds containing gum arabic (Slongo et al., 2009; Kreyenschmidt et al., 2010). 


\subsection{Modeling the growth of lactic acid bacteria and total viable counts}

\section{Lactic acid bacteria}

The growth kinetics of Lactic Acid Bacteria (LAB) obtained from both Baranyi model and Gompertz model are shown in Table 1. The changes in LAB population in cured beef rounds containing gum arabic stored at $7{ }^{\circ} \mathrm{C}$ and 15 ${ }^{\circ} \mathrm{C}$, as predicted by both Baranyi and modified Gompertz models, are shown in Figures 1 and 2. Initial counts of LAB in cooked injected beef rounds were below $1 \log _{10} \mathrm{CFU} \mathrm{g}^{-1}$. These were very close to the total viable counts and reached the upper asymptote of the sigmoid curve at counts between $10^{7.681}-10^{7.824} \mathrm{CFU} \mathrm{g}^{-1}$ throughout the storage period at both temperatures. These values were very close to those found by Pexara, Metaxopoulos, and Drosinos (2002). In their research on evaluation of shelf life of cured, cooked, sliced turkey fillets and cooked pork sausages stored under vacuum and modified atmospheres at +4 and $+10{ }^{\circ} \mathrm{C}$, they found that the maximum growth level for $\mathrm{LAB}$ was $10^{8} \mathrm{CFU} \mathrm{g}^{-1}$. This proves that LABs are the SSO of cured vacuum packaged beef (Slongo et al., 2009; Kreyenschmidt et al., 2010). This also agrees with Mataragas, Drosinos, Vaidanis, and Metaxopoulos (2006). In their study on the spoilage of cooked cured meat products their results showed that the SSOs were the LAB and their maximum population was between $10^{8.3}$ $10^{8.9} \mathrm{CFU} \mathrm{g}^{-1}$ which they considered to be the spoilage level. This is because the combination of microaerophilic conditions, presence of sodium chloride and sodium nitrite inhibits growth of gram negative spoilage microorganisms, but favors growth of $\mathrm{LAB}(\mathrm{Hu}, \mathrm{Zhou}, \mathrm{Xu}, \mathrm{Li}, \& \mathrm{Han}$, 2009). This explains the high percentage of LAB in the TVC in the beef round samples.

Different microbial growth parameters were observed at different temperatures and for the different models applied. By comparing the statistical indices (RMSE and $\mathrm{R}^{2}$ ) of primary models, differences (of the models) in their ability to describe the experimental data at $7{ }^{\circ} \mathrm{C}$ and $15{ }^{\circ} \mathrm{C}$ were observed. The $\mathrm{R}^{2}$ was used to provide a scale to evaluate how reliable results could be predicted using both models. Both Baranyi and the modified Gompertz models accurately described the growth of LAB in cured beef rounds containing gum arabic at both temperatures owing to their $\mathrm{R}^{2}$ values above 0.90 . Moreover, the Baranyi model better described the growth data sets at $15^{\circ} \mathrm{C}$ for both $\mathrm{LAB}, \mathrm{R}^{2}=0.969$ and TVC, $\mathrm{R}^{2}=0.966$ and at $7{ }^{\circ} \mathrm{C}$ for $\mathrm{TVC}, \mathrm{R}^{2}=0.992$. The modified Gompertz model better fitted the data for $\mathrm{LAB}$ at $7{ }^{\circ} \mathrm{C}$ with $\mathrm{R}^{2}=0.954$. Similar trends were seen for comparisons based on the RMSE. The low RMSE values indicate better fit and higher accuracy of the models (Cayre et al., 2003; Sant'Ana, Franco, \& Schaffner, 2012). Other studies have indicated that the modified Gompertz model (Mataragas et al., 2006; Kreyenschmidt et al., 2010) and the Baranyi model (Feng, Drummond, \& Sun, 2014) can adequately describe the growth of microorganisms in meat products.

Growth rates predicted by the Baranyi model were lower than those predicted by the modified Gompertz model for both LAB at both temperatures. Previous researchers have reported the possibility of overestimation of the rate of growth by the Gompertz model (Gibson, Bratchell, \& Roberts, 1988). Moreover, the rate of growth of LAB were highest at $15{ }^{\circ} \mathrm{C}$ as compared to $7{ }^{\circ} \mathrm{C}$. Increase in temperature from $7{ }^{\circ} \mathrm{C}$ to $15{ }^{\circ} \mathrm{C}$ almost doubled the rate of growth as predicted by both models. These rates were higher than those reported by Kreyenschmidt et al. (2010)) who reported the rate of growth of LAB at $7{ }^{\circ} \mathrm{C}$ and 15 ${ }^{\circ} \mathrm{C}$ as $0.009 \mathrm{CFU} \mathrm{g}^{-1} \mathrm{~h}^{-1}$ and $0.038 \mathrm{CFU} \mathrm{g}^{-1}$ $\mathrm{h}^{-1}$, respectively. This can be explained by the difference in the samples used as well as the possible differences in intrinsic properties and contaminating bacteria in the meat samples. The type of packaging used was also different. Whereas this research utilized vacuum packaging, modified atmosphere packaging was used in their research.

\section{Total Viable Counts}

The growth kinetics of TVC obtained from both Baranyi and modified Gompertz models are shown in Table 1. The changes in TVC population in cured beef rounds containing gum ara- 
Beef rounds containing gum arabic $\mid 29$

Table 1: Predicted bacterial growth parameters at $7^{\circ} \mathrm{C}$ and $15^{\circ} \mathrm{C}$

\begin{tabular}{|c|c|c|c|c|c|c|c|c|}
\hline \multirow[b]{3}{*}{ Temperature $\left( \pm 0.2{ }^{\circ} \mathrm{C}\right)$} & \multicolumn{4}{|c|}{ Baranyi Model } & \multicolumn{4}{|c|}{ modified Gompertz Model } \\
\hline & \multicolumn{2}{|c|}{ LAB } & \multicolumn{2}{|c|}{ TVC } & \multicolumn{2}{|c|}{ LAB } & \multicolumn{2}{|c|}{ TVC } \\
\hline & 15 & 7 & 15 & 7 & 15 & 7 & 15 & 7 \\
\hline$\mu_{\max }\left(\mathrm{CFU} \mathrm{g} \mathrm{g}^{-1} \mathrm{~h}^{-1}\right)$ & 0.081 & 0.036 & 0.073 & 0.040 & 0.110 & 0.058 & 0.088 & 0.051 \\
\hline$\lambda(\mathrm{h})$ & - & - & - & - & $6.63 \mathrm{E}-08$ & $1.05 \mathrm{E}-07$ & $7.48 \mathrm{E}-08$ & $3.92 \mathrm{E}-07$ \\
\hline$N_{0}\left(\log ^{10} \mathrm{CFU} \mathrm{g}^{10-1}\right)$ & 0.646 & 0.955 & 1.116 & 1.005 & 0.034 & 0.170 & 0.658 & 0.486 \\
\hline$N_{\max }\left(\log ^{10} \mathrm{CFU} \mathrm{g}^{-1}\right)$ & 7.824 & 7.811 & 8.230 & 7.940 & 7.787 & 7.681 & 8.243 & 7.992 \\
\hline $\mathrm{R}^{2}$ & 0.969 & 0.946 & 0.966 & 0.992 & 0.961 & 0.954 & 0.952 & 0.990 \\
\hline RMSE & 0.529 & 0.717 & 0.559 & 0.274 & 0.595 & 0.665 & 0.660 & 0.307 \\
\hline
\end{tabular}

TVC is Total Viable Counts, LAB is Lactic Acid Bacteria, $\mu_{\max }$ is maximum growth rate, $\lambda$ is Lag time, $N_{o}$ is the initial point of the sigmoid curve, $N_{\max }$ is the upper asymptote of the sigmoid curve, $\mathrm{R}_{2}$ is the coefficient of determination and RMSE is the Root Mean Squares Error.

Table 2: Predicted shelf life at $7{ }^{\circ} \mathrm{C}$ and $15{ }^{\circ} \mathrm{C}$

\begin{tabular}{cccc}
\hline & Temperature & \multicolumn{2}{c}{ Predicted Shelf life $(\mathrm{h})$} \\
\cline { 3 - 4 } & $\left( \pm 0.2{ }^{\circ} \mathrm{C}\right)$ & Baranyi Model & modified Gompertz Model \\
\hline LAB & 15 & 84.316 & 85.973 \\
TVC & 15 & 84.390 & 88.096 \\
LAB & 7 & 173.063 & 160.982 \\
TVC & 7 & 157.979 & 160.622 \\
\hline
\end{tabular}

TVC is Total Viable Counts, LAB is Lactic Acid Bacteria

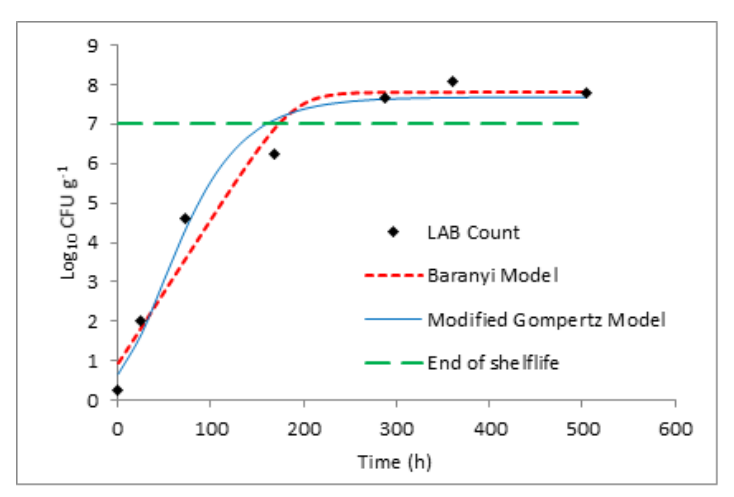

Figure 1: Changes in LAB population in cured beef rounds containing gum arabic stored at $7{ }^{\circ} \mathrm{C}$ as predicted by Baranyi and modified Gompertz models

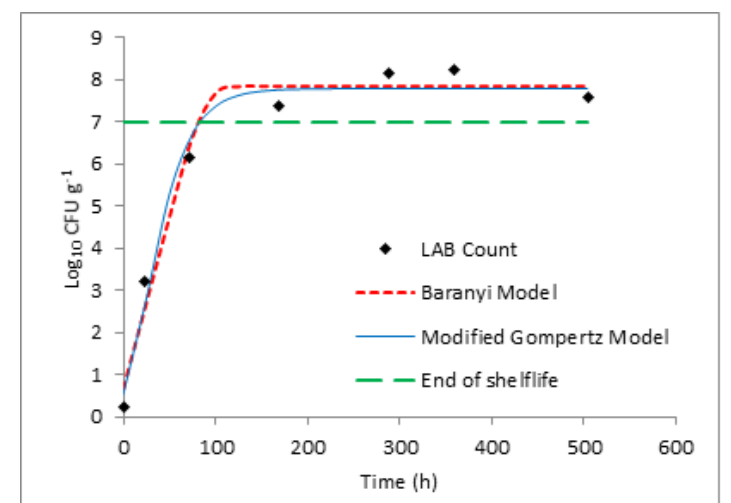

Figure 2: Changes in LAB population in cured beef rounds containing gum arabic stored $15{ }^{\circ} \mathrm{C}$ as predicted by Baranyi and modified Gompertz models 
bic stored at $7{ }^{\circ} \mathrm{C}$ and $15{ }^{\circ} \mathrm{C}$ as predicted by both Baranyi and modified Gompertz models are shown in Figures 3 and 4. The TVC were very close to the LAB counts and reached the upper asymptote of the sigmoid curve at counts between $10^{7.940}-10^{8.243} \mathrm{CFU} \mathrm{g}^{-1}$ throughout the storage period at both temperatures. This agrees with Kreyenschmidt et al. (2010). In their research on determination of the shelf life of sliced cooked hams based on the growth of lactic acid bacteria, they found that the TVC attained a plateau within the range 7.9 and 8.7 $\log _{10} \mathrm{CFU} \mathrm{g}^{-1}$. Initial counts of TVC in cooked injected beef rounds were below $1 \log _{10} \mathrm{CFU}$ $\mathrm{g}^{-1} \mathrm{~h}^{-1}$. The predicted asymptotic growth levels for TVC as predicted by the Baranyi model were lower than those predicted by the modified Gompertz model at both temperatures. Similarly, as previously noted in the growth of LAB, the growth rates predicted by Baranyi model were lower than those predicted by the modified Gompertz model at both temperatures. This could be explained by the report of Gibson et al. (1988) on the possibility of over estimation of rates of growth by Gompertz model. Nevertheless, both models adequately described the growth of TVC and LAB as shown by the high $\mathrm{R}^{2}$ values. Other researchers have reported similar results (Mataragas et al., 2006; Kreyenschmidt et al., 2010; Feng et al., 2014). Increase in temperature from $7{ }^{\circ} \mathrm{C}$ to $15{ }^{\circ} \mathrm{C}$ nearly doubled the rate of growth of microorganisms as predicted in both models. Furthermore, lag time values predicted by the modified Gompertz model were almost negligible and thus nearly zero as assumed in the Baranyi model.

\section{Predicted shelf life}

Time taken to reach $7 \log _{10}$ CFU g $\mathrm{g}^{-1} \mathrm{~h}^{-1}$ according to Kreyenschmidt et al. (2010) and Slongo et al. (2009) as estimated by the Baranyi and modified Gompertz models are shown in Table 2. Shelf life taken as the time required to reach $7 \log _{10} \mathrm{CFU} \mathrm{g}{ }^{-1} \mathrm{~h}^{-1}$ yielded different results depending on the model applied and the temperature of prediction. The range of shelf life values predicted by both models was between $84.3-88.1 \mathrm{~h}$ and $158.0-173.1 \mathrm{~h}$ at $15{ }^{\circ} \mathrm{C}$ and $7{ }^{\circ} \mathrm{C}$, respectively. These values are lower than

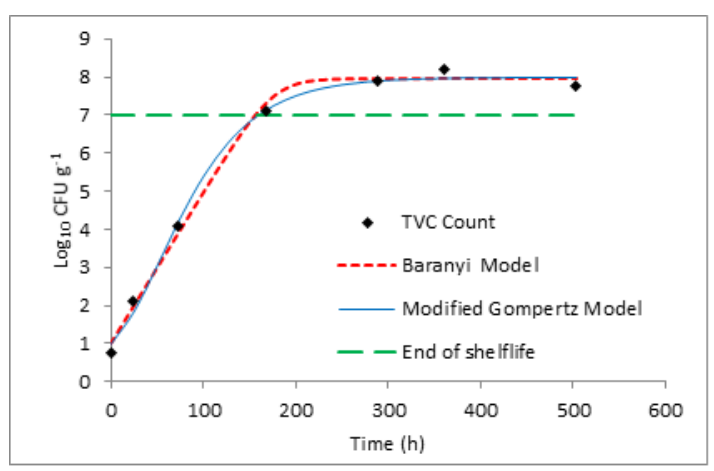

Figure 3: Changes in TVC population in cured beef rounds containing gum arabic stored at $7{ }^{\circ} \mathrm{C}$ as predicted by Baranyi and modified Gompertz modelss

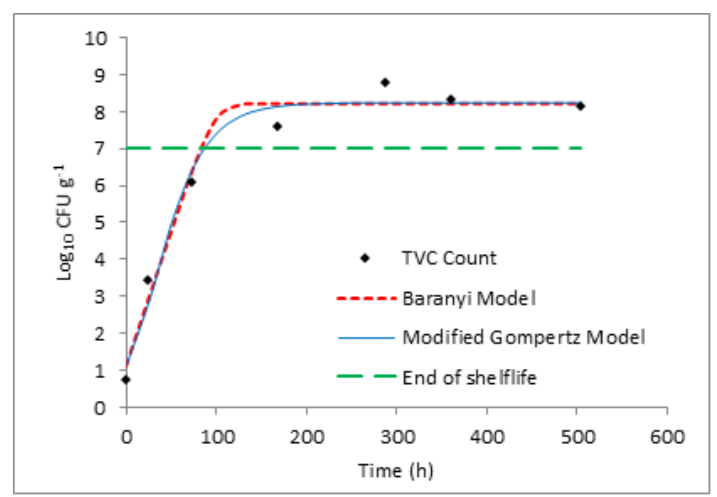

Figure 4: Changes in TVC population in cured beef rounds containing gum arabic stored at 15 ${ }^{\circ} \mathrm{C}$ as predicted by Baranyi and modified Gompertz models 
those reported by Kreyenschmidt et al. (2010) for hams stored at $7^{\circ} \mathrm{C}$ but comparable for those stored at $15{ }^{\circ} \mathrm{C}$. In their research, they reported that hams could stay for $302.2 \mathrm{~h}$ and $92.5 \mathrm{~h}$ at $7{ }^{\circ} \mathrm{C}$ and $15{ }^{\circ} \mathrm{C}$, respectively. This may be because of variations in the contaminating bacteria which might have been different in both studies. Furthermore, ingredients and processes used for making cured meat products were not entirely the same. Whereas their research used modified atmosphere packaging $\left(80 \% \mathrm{~N}_{2}+20 \% \mathrm{CO}_{2}\right)$, this research employed vacuum packaging. According to Skandamis and Nychas (2002), modified atmosphere packaging involving combination of $\mathrm{CO}_{2}$ and $\mathrm{N}_{2}$ gases preserves meat better than vacuum packaging.

Predicted shelf life values were higher in the modified Gompertz model at $15{ }^{\circ} \mathrm{C}$ than in Baranyi model as shown in Table 2. These almost doubled when temperature was changed to $7^{\circ} \mathrm{C}$. This agrees with the modeled parameters discussed before in Table 1 in which the rates of growth almost doubled with the change in temperatures. Mataragas et al. (2006) had set the safety limit to $8.3 \log _{10} \mathrm{CFU} \mathrm{g} \mathrm{g}^{-1} \mathrm{~h}^{-1}$. Based on this information, all samples would still be fit for consumption even at day 21 as none of the samples had reached that microbial concentration.

This study gives an initial investigation of microbial quality and shelf life determination limited to beef rounds injected to $30 \%$ containing $2.5 \%$ gum arabic. In addition, the study is limited to beef rounds stored at $7{ }^{\circ} \mathrm{C}$ and $15{ }^{\circ} \mathrm{C}$. Therefore, further studies are required to estimate shelf life based on sensory appeal of the product so as to correctly estimate the keeping quality of beef rounds. This is because sensory evaluation best determines the limit of acceptability of a food product (Mataragas et al., 2007) which may not always coincide with the limit of bacterial counts in meat products. A combination of both bacteria counts and sensory evaluation methods will provide a more accurate estimation of shelf life.

\section{Conclusions}

This study has provided a kinetic model that was able to predict the growth of microorganisms during anaerobic storage of beef rounds stored at
7 and $15{ }^{\circ} \mathrm{C}$ for 21 days. When fitted the range of shelf life values obtained in both Baranyi and modified Gompertz models were between 84.3 $88.1 \mathrm{~h}$ at $15^{\circ} \mathrm{C}$ and $158.0-173.1 \mathrm{~h}$ at $7^{\circ} \mathrm{C}$. Both Baranyi and the modified Gompertz models accurately described the growth of LAB and TVC in cured beef rounds containing gum arabic at both temperatures when using DMFit. These results are of practical importance in evaluating the shelf life of vacuum packaged beef rounds containing gum arabic from Acacia senegal Var. kerensis.

\section{Acknowledgements}

This research was funded through a research grant from the Association of African Universities, Accra, Ghana and the Egerton University Council Graduate Scholarship. Assistance from Castle Meat Products factory, Njoro, Kenya is highly appreciated.

\section{References}

Aggelis, G., Samelis, J., \& Metaxopoulos, J. (1998). A novel modelling approach for predicting microbial growth in a raw cured meat product stored at 3 degrees $\mathrm{c}$ and at 12 degrees c in air. International Journal of Food Microbiology, 43(1-2), 39-52. doi:10.1016/S0168-1605(98)00095-6

AOAC. (2000). Official Methods of Analysis of AOAC International (17th Ed.) AOAC International. Maryland: Gaithersburg.

Baranyi, J. \& Roberts, T. A. (1994). A dynamic approach to predicting bacterial-growth in food. International Journal of Food Microbiology, 23(3-4), 277-294. doi:10.1016/ 0168-1605(94)90157-0

Cayre, M., Vignolo, G., \& Garro, O. (2003). Modeling lactic acid bacteria growth in vacuum-packaged cooked meat emulsions stored at three temperatures. Food $\mathrm{Mi}$ crobiology, 20(5), 561-566. doi:10.1016/ S0740-0020(02)00154-5

FAO/WHO. (2005). Combined Compendium of Food Additive Specifications: Analytical methods, test procedures and laboratory solutions used by and referenced in food ad- 
ditive specifications. Expert Committee on Food Additive. Food \& Agriculture Org.

Feng, C.-H., Drummond, L., \& Sun, D.-W. (2014). Modelling the growth parameters of lactic acid bacteria and total viable count in vacuum-packaged irish cooked sausages cooled by different methods. International Journal of Food Science and Technology, 49(12), 2659-2667. doi:10.1111/ijfs.12603

Feng, C.-H., Sun, D.-W., Martin, J. F. G., \& Zhang, Z.-H. (2013). Effects of different cooling methods on shelf-life of cooked jumbo plain sausages. LWT-Food Science and Technology, 54(2), 426-433. doi:10 . 1016/j.lwt.2013.05.033

Fu, B. \& Labuza, T. P. (1997). Shelf-life testing: procedures and prediction methods. In M. C. Erickson \& Y.-C. Hung (Eds.), Quality in frozen food (pp. 377-415). Boston, MA: Springer US. doi:10.1007/978-1-46155975-7_19

Gibson, A. M., Bratchell, N., \& Roberts, T. A. (1988). Predicting microbial-growth - growth-responses of salmonellae in a laboratory medium as affected by ph, sodiumchloride and storage-temperature. International Journal of Food Microbiology, 6(2), 155-178. doi:10.1016/0168-1605(88)900517

Gibson, A. M. \& Roberts, T. A. (1989). Predicting microbial-growth - development of a mathematical-model to predict bacterialgrowth responses. Food Australia, 41(12), 1075-1079. 6th Australian food microbiology conf, surfers paradise, Australia, sep 04-07, 1988.

Hamasaki, Y., Ayaki, M., Fuchu, H., Sugiyama, M., \& Morita, H. (2003). Behavior of psychrotrophic lactic acid bacteria isolated from spoiling cooked meat products. Applied and Environmental Microbiology, 69(6), 3668-3671. doi:10.1128/AEM.69 . $6.3668-3671.2003$

Hongpattarakere, T., Rattanaubon, P., \& Buntin, N. (2013). Improvement of freezedried lactobacillus plantarum survival using water extracts and crude fibers from food crops. Food and Bioprocess Technology, 6(8), 1885-1896. doi:10.1007/s11947012-1018-Z
Hu, P., Zhou, G., Xu, X., Li, C., \& Han, Y. (2009). Characterization of the predominant spoilage bacteria in sliced vacuumpacked cooked ham based on 16s rdnadgge. Food Control, 20(2), 99-104. doi:10. 1016/j.foodcont.2008.02.007

Kreyenschmidt, J., Huebner, A., Beierle, E., Chonsch, L., Scherer, A., \& Petersen, B. (2010). Determination of the shelf life of sliced cooked ham based on the growth of lactic acid bacteria in different steps of the chain. Journal of Applied Microbiology, 108(2), 510-520. doi:10.1111/j.1365-2672. 2009.04451.x

Li, M. Y., Sun, X. M., Zhao, G. M., Huang, X. Q., Zhang, J. W., Tian, W., \& Zhang, Q. H. (2013). Comparison of mathematical models of lactic acid bacteria growth in vacuum-packaged raw beef stored at different temperatures. Journal of Food Science, 78(4), 600-604. doi:10.1111/j.17503841.2012.02995.x

Liu, F., Yang, R., \& Li, Y. (2006). Correlations between growth parameters of spoilage micro-organisms and shelf-life of pork stored under air and modified atmosphere at -2, 4 and 10 degrees c. Food $M i$ crobiology, 23(6), 578-583. doi:10.1016/j. fm.2005.10.002

Mataragas, M., Drosinos, E. H., Vaidanis, A., \& Metaxopoulos, I. (2006). Development of a predictive model for spoilage of cooked cured meat products and its validation under constant and dynamic temperature storage conditions. Journal of Food Science, 71(6), 157-167. doi:10.1111/j.17503841.2006.00058.x

Mataragas, M., Skandamis, P., Nychas, G.-J. E., \& Drosinos, E. H. (2007). Modeling and predicting spoilage of cooked, cured meat products by multivariate analysis. Meat Science, 77(3), 348-356. doi:10.1016/j . meatsci.2007.03.023

Mwove, J. K., Gogo, L. A., Chikamai, B. N., Omwamba, M. N., \& Mahungu, S. M. (2016). Preparation and quality evaluation of extended beef rounds containing gum arabic from acacia senegal var. kerensis. Food and Nutrition Sciences, 7(11), 977. doi:10.4236/fns.2016.711096 
Nychas, G.-J. E., Skandamis, P. N., Tassou, C. C., \& Koutsoumanis, K. P. (2008). Meat spoilage during distribution. Meat Science, 78(1-2), 77-89. Meeting of the middle section of the American Laryngological, Rhinological and Otological soc inc, Chicago, il, jan 25-26, 1986. doi:10.1016/j.meatsei. 2007.06.020

Perez-Chabela, M. L., Lara-Labastida, R., Rodriguez-Huezo, E., \& Totosaus, A. (2013). Effect of spray drying encapsulation of thermotolerant lactic acid bacteria on meat batters properties. Food and Bioprocess Technology, 6(6), 1505-1515. doi:10.1007/s11947-012-0865-y

Pexara, E., Metaxopoulos, J., \& Drosinos, E. (2002). Evaluation of shelf life of cured, cooked, sliced turkey fillets and cooked pork sausages 'piroski' stored under vacuum and modified atmospheres at +4 and +10 degrees c. Meat Science, 62(1), 33-43. doi:10.1016/S0309-1740(01)00224-8

Ray, B. \& Bhunia, A. (2007). Fundamental food microbiology. CRC press.

Samelis, J. \& Georgiadou, K. (2000). The microbial association of greek taverna sausage stored at 4 and 10 degrees $\mathrm{c}$ in air, vacuum or $100 \%$ carbon dioxide, and its spoilage potential. Journal of Applied Microbiology, 88(1), 58-68. doi:10.1046/j. 1365 - 2672 . 2000.00936.x

Sant'Ana, A. S., Franco, B. D. G. M., \& Schaffner, D. W. (2012). Modeling the growth rate and lag time of different strains of salmonella enterica and listeria monocytogenes in ready-to-eat lettuce. Food $\mathrm{Mi}$ crobiology, 30(1), 267-273. doi:10.1016/j. fm.2011.11.003

Santos, E., Jaime, I., Rovira, J., Lyhs, U., Korkeala, H., \& Bjorkroth, J. (2005). Characterization and identification of lactic acid bacteria in "morcilla de burgos". International Journal of Food Microbiology, 97(3), 285-296. doi:10.1016/j.ijfoodmicro. 2004. 04.021

Simonin, H., Duranton, F., \& de Lamballerie, M. (2012). New insights into the high-pressure processing of meat and meat products. Comprehensive Reviews in Food Science and Food Safety, 11(3), 285-306. doi:10 . 1111/j.1541-4337.2012.00184.x

Skandamis, P. \& Nychas, G. (2002). Preservation of fresh meat with active and modified atmosphere packaging conditions. International Journal of Food Microbiology, 79(1-2, SI), 35-45. International Symposium on Frontiers in Microbial Preservation and Fermentation, Wageningen, Netherlands, Jan 09-11, 2002. doi:10.1016/S01681605(02)00177-0

Slongo, A. P., Rosenthal, A., Quaresma Camargo, L. M., Deliza, R., Mathias, S. P., \& Falcao de Aragao, G. M. (2009). Modeling the growth of lactic acid bacteria in sliced ham processed by high hydrostatic pressure. LWT-Food Science and Technology, 42(1), 303-306. doi:10.1016/j. lwt . 2008.06.010

Steele, J. E. \& Stiles, M. E. (1981). Microbial quality of vacuum packaged sliced ham. Journal of Food Protection, 44 (6), 435-\&.

Sutherland, J. P., Bayliss, A. J., \& Roberts, T. A. (1994). Predictive modeling of growth of staphylococcus-aureus - the effects of temperature, ph and sodium-chloride. International Journal of Food Microbiology, 21 (3), 217-236. doi:10.1016/0168-1605(94)900299

Vermeiren, L., Devlieghere, F., De Graef, V., \& Debevere, J. (2005). In vitro and in situ growth characteristics and behaviour of spoilage organisms associated with anaerobically stored cooked meat products. Journal of Applied Microbiology, 98(1), 33-42. doi:10.1111/j.1365-2672.2004.02443.x 